\title{
Scale for Measuring the Attitude of Farmers towards Sustainable Cultivation Practices of Pineapple
}

\author{
Sentibenla Pongener* and Kaushal Kumar Jha \\ Department of Agricultural Extension, Nagaland University: SASRD, \\ Medziphema Campus, Nagaland, India \\ *Corresponding author
}

\section{A B S T R A C T}

Keywords

Attitude, Pineapple farmers, Reliability, Validity, Scale

Article Info

Accepted:

10 November 2019

Available Online:

10 December 2019
Attitude refers to the degree of positive or negative affect associated with some psychological object. The present study was conducted to develop an attitude scale for measuring the attitude of farmers towards sustainable cultivation practices of Pineapple. Likert's summative rating technique of scale construction was used. The procedure of developing included item collection, editing of items, item analysis and calculating scale values of each of the scale items. The final scale consisted of 14 statements including 6 positive and 8 negative statements. The scale so developed was subjected to the reliability and validity tests. Reliability of the scale was calculated by using split half method and reliability coefficient was 0.85 . The results of reliability and validity of the scale indicated that the scale can be used to measure the attitude of farmers towards adoption of sustainable cultivation practices of Pineapple.

\section{Introduction}

Agriculture has been the backbone of mankind's survival since the dawn of time. Agriculture has not only provided food but generated income and employment throughout the years thereby, contributing a good share to the world's economy. With the increase in population and globalization, the same piece of land is being used for farming practices year after year for many generations. The continuous use of land, air and water and application of chemicals, herbicides and pesticides to meet the ever increasing needs of the present population is posing a huge threat to our environment. Soil erosion, degradation, water and air pollution, forest wildfire, climate and depletion of natural resources are some of the major concerns of present generation as a result of irresponsible actions of the humanity. Pineapple being an exhaustive crop, the soil and the surrounding vegetation gets 
deteriorated within a couple of years. The depletion in soil health can be minimized to a certain level when the pineapple growers practice sustainable agriculture. In 1987, the United Nations Brundtland Commission defined sustainability as "meeting the needs of the present without compromising the ability of future generations to meet their own needs."

According to Food and Agriculture Organization (2015), to be sustainable, agriculture must meet the needs of present and future generations for its products and services, while ensuring profitability, environmental health and social and economic equity. The importance of judiciously using the natural resources are imparted to the pineapple farming community by various organizations, universities and allied departments over the years. The degree of acceptance or denial of practicing sustainable farming in pineapple cultivation depends upon the attitude of the farmers.

Attitude refers to the "degree of positive or negative affect associated with some psychological object' (Thurstone, 1946). Attitude is a predisposition to act in a certain way. It is the state of readiness that influences a person to act in a given manner (Rahman et al., 1999). Attitude plays an important role in adoption of recommended practices by farmers leading to higher productivity and profitability. A farmer's decision to adopt environment friendly agricultural practices depends upon his favourable attitude. Attitude measurement will help researchers in providing an adequate explanation on farmers' perception towards sustainable agricultural practices and can be used on developing strategies and policies related to sustainable issues. Thus, it was imperative to know the attitude of famers towards sustainable pineapple cultivation practices. Therefore an attempt was made to develop an attitude scale for measuring the attitude of farmers towards sustainable cultivation practices of Pineapple. Sadati et al., (2010) found out from their study that extension contacts', farmers' knowledge about sustainable agriculture, job satisfaction and literacy are effective factors on farmers' attitude toward sustainable agriculture. Ghosh and Hasan (2013) revealed from their study that education, farm size, annual income, cosmopoliteness, extension contact and knowledge showed positive significant relationship with the attitude of the farmers towards sustainable agricultural practices.

As attitude of farmers determine their adoption behaviour in terms of following the improved practices, a research study was conducted during 2017-2019 to develop a scale based on Likert's technique.

\section{Materials and Methods}

Method of summated rating suggested by Likert (1932) was followed for construction of attitude scale. Likert scaling is a psychometric concept commonly used in survey research that uses guide questionnaires that need responses in scales from the subject or respondents of interest. It is a widely used scale in many field of discipline most particularly in the social science research like in education and psychology. It is a scaling method in which a statement can be responded positively or negatively (Pimentel, 2019). This technique is moderately simple, time-saving and offers opportunities to select statements based on their discriminating power. Following steps were followed to develop the desired attitude scale:

\section{Item collection}

The items making up an attitude scale are called 'Statements'. A statement may be defined as anything that is said about a psychological object or stimulus. Statements 
on sustainable pineapple cultivation practices were first collected to construct the attitude scale. The statements, both favourable and unfavourable reflecting various dimension of attitudes were collected using the help of various books, bulletins, magazines, and by discussions with academicians, subject matter specialists, researchers, who were directly or indirectly exposed to such knowledge system. Initially, a total of 92 statements (50 positive and 42 negative statements) relevant to sustainable pineapple cultivation practices were collected.

\section{Editing of items}

Criteria suggested by Edwards (1957) were followed to edit the collected statements. All the 92 statements were scrutinised with the help of experts out of which 50 statements were retained. Efforts were made to compose each statement with minimum possible words as well as clarity in meaning and understanding. The researcher also made sure that both positive and negative statements were included.

\section{Item analysis}

Item analysis is an important step in the construction of a valid and reliable scale. The purpose of an item analysis is to find those items that form an internally consistent scale and to eliminate those items that do not (Spector, 1992). The edited 50 statements were subjected to item analysis to delineate the items that discriminate between persons having favourable and unfavourable attitudes.

The response of respondents for each statements were obtained on a five point continuum ranging from, 'strongly agree', 'agree', 'undecided', 'disagree', and 'strongly disagree' with the weighted scores of $5,4,3$, 2 , and 1 respectively for positive statements and reverse scoring system was employed for negative statements. The total score for each individual was computed by summing up the scores over all items.

\section{Computation of ' $t$ ' value}

For computation of $\mathrm{t}$ value, all 50 scale items were administered to a random sample of 20 farmers from non-sampled area. Total scores were obtained for each the respondents based on the sum of the scores of all individual 50 statements on 5 point continuum. The top 27 per cent of respondents having high total score (high group) and the bottom 27 per cent of the respondents with low score (low group), were used as criterion group to evaluate individual scale items. The critical ratio ( $t$-value) for each item was calculated by using the formula given by Edwards (1957) as follows:

$t=\frac{\bar{X}_{H}-\bar{X}_{L}}{\sqrt{\frac{\sum\left(x_{H}-z_{H}\right)^{2}+\sum\left(x_{L}-z_{L}\right)^{2}}{n(n-1)}}}$

Where,

$\sum\left(X_{H}-\bar{X}_{H}\right)^{2}=\sum\left(X_{H}\right)^{2}-\frac{\left(\sum X_{H}\right)^{2}}{n}$

$\sum\left(X_{L}-\bar{X}_{L}\right)^{2}=\sum\left(X_{L}\right)^{2}-\frac{\left(\sum X_{L}\right)^{2}}{n}$

$\bar{X}_{H}=$ Mean score of given statement of high group

$\bar{X}_{L}=$ Mean score of given statement in low group

$\Sigma\left(X_{H}\right)^{2}=$ Sum of squares of individual score on a given statement for high group

$\Sigma\left(X_{L}\right)^{2}=$ Sum of squares of individual score on a given statement for low group

$\sum X_{H}=$ Summation of scores on given statement for high group 
$\sum X_{L}=$ Summation of scores on given statement for low group

$\mathrm{n}=$ Number of respondents in each group

The statements were arranged in descending order based on the ' $t$ ' values of the statements for final selection of scale items.

\section{Testing the reliability and validity of scale}

Reliability was calculated using the split- half technique where the scale was divided into two halves based on odd and even number of statements. The co-efficient of reliability between the two sets of score was calculated by using Spearman-Brown (1910) prophecy formula cited by Zeller and Carmines (1980) which is given below:

$R=\frac{2 r}{1+r}$

Where, $R=$ Reliability coefficient of the whole scale

$r=$ Estimated correlation between two halves (Pearson r)

Further the validity of scale was tested using content validity criterion.

\section{Results and Discussion}

Critical ratio (' $t$ ' value) of each statement was calculated for the final selection of items. Items or statements which had ' $t$ ' value equal to or, greater than 1.75 were selected as this ' $t$ ' value significantly brought differentiation between high and low groups of items (Edwards, 1957).

A total of 14 statements ( 6 positive and 8 negative statements) had ' $t$ ' value equal to or greater than 1.75 and hence, these statements were selected for including as scale items for the attitude scale as shown in Table 1.

\section{Qualities of a good scale}

A good summated rating scale is both reliable and valid. Reliability may be considered in two ways. First, test-retest reliability means that a scale yields consistent measurement over time. In this case we assume that the construct of interest does not change, each subject should get about the same score upon repeated testing. Second, internal-consistency reliability means that multiple items, designed to measure the same construct, will intercorrelate with one another.

It is possible that a scale demonstrates only one of these types of reliability. Reliability assures that a scale can consistently measure something, but it does not assure that it will measure what it is designed to measure (Spector, 1992). This property that a scale measures its intended construct is validity. In present case split half technique of reliability and content validity was undertaken for testing the reliability and validity of the scale developed.

\section{Reliability of the scale}

According to Ray and Mondal (1999), reliability refers to the precision or accuracy of measurement or score. Reliability was carried out to know the consistency, stability and accuracy of the scale. The selected 14 statements were divided into two halves of 7 odd and 7 even statements. The test was conducted on respondents from non sampled area. The correlation coefficient value between the two sets of score was 0.74 .

The calculated value of reliability coefficient for the test was 0.85. Lin et al., (2007) used the 3 point Likert scale and found test-retest coefficient $(\mathrm{N}=45)$ as 0.65 . Thus, the attitude scale developed for measuring the attitude of farmers towards sustainable cultivation practices of Pineapple was found to be reliable. 
Table.1 List of selected scale statements

\begin{tabular}{|c|c|c|}
\hline Sl. No. & Statements & 't' values \\
\hline 1. & $\begin{array}{l}\text { One should go for adopting sustainable pineapple cultivation practices } \\
\text { as it is beneficial to farmers. (+) }\end{array}$ & 1.898 \\
\hline 2. & $\begin{array}{l}\text { Sustainable pineapple cultivation practices can be practiced only by } \\
\text { small farmers. (-) }\end{array}$ & 1.890 \\
\hline 3. & $\begin{array}{l}\text { Soil and water resources belong to only the present generation and so } \\
\text { maximum resources must be used to make it sustainable. (-) }\end{array}$ & 2.127 \\
\hline 4. & $\begin{array}{l}\text { Sustainable pineapple cultivation practices benefits only the producers } \\
\text { and not the environment. (-) }\end{array}$ & 2.000 \\
\hline 5. & $\begin{array}{l}\text { A farmer should prepare compost from the farm waste in sustainable } \\
\text { cultivation practices. }(+)\end{array}$ & 2.142 \\
\hline 6. & $\begin{array}{c}\text { Maintaining good drainage system is not a sustainable practice in } \\
\text { pineapple cultivation. }(-)\end{array}$ & 1.789 \\
\hline 7. & $\begin{array}{l}\text { In order to sustainably manage a pineapple farm, a farmer should } \\
\text { essentially go for curing of suckers and slips. }(+)\end{array}$ & 4.000 \\
\hline 8. & $\begin{array}{l}\text { A farmer should not be aware that drip irrigation help in maintaining } \\
\text { optimum growth of the plant in sustainable pineapple cultivation. (-) }\end{array}$ & 2.000 \\
\hline 9. & $\begin{array}{l}\text { Biocontrol is not a sustainable practice to control the insect-pest } \\
\text { population in pineapple field. (-) }\end{array}$ & 1.898 \\
\hline 10. & $\begin{array}{l}\text { One should opt for adopting biological pest control practices in } \\
\text { sustainable cultivation practices. }(+)\end{array}$ & 2.000 \\
\hline 11. & $\begin{array}{l}\text { More pesticide and weedicide are required for controlling pests and } \\
\text { weeds in sustainable cultivation practices. (-) }\end{array}$ & 2.000 \\
\hline 12. & $\begin{array}{l}\text { A farmer must practice mulching the pineapple plantation with black } \\
\text { polysheet to conserve the soil moisture and check soil erosion. }(+)\end{array}$ & 2.667 \\
\hline 13. & $\begin{array}{l}\text { Using black polythene film as mulch is a sustainable method of } \\
\text { controlling weed growth and conserving soil moisture in sustainable } \\
\text { pineapple cultivation. }(+)\end{array}$ & 2.272 \\
\hline 14. & $\begin{array}{l}\text { Desuckering practice in pineapple population is not advisable for } \\
\text { sustainable cultivation. (-) }\end{array}$ & 2.132 \\
\hline
\end{tabular}

\section{Validity of the scale}

Validity is often defined as the extent to which an instrument measures what it asserts to measure (Blumberg et al., 2005).

Validity and reliability increase transparency and decrease opportunities to insert research bias in qualitative research (Singh, 2014). It covers the entire experimental concept and establishes whether the results obtained satisfy all of the requirements of the scientific research method. Validity requires the research instrument to correctly measure the concepts under the study (Pallant, 2011). The validity of the scale was examined for content validity by determining how well the content of the scale represented the domain subject matter under study (Chovatia et al., 2017). According to Kerlinger (1987) content validity of scale is the representative or sampling adequacy of the content, the substance, the matter and the topics of a measuring instrument. The items were selected by 
discussion with specialists, extension academicians, and adherence to the judges' ratings and by reviewing the literature. Hence, the present scale satisfied the content validity.

\section{Administration of the scale}

The final attitude scale consisting of 14 statements can be administered to the pineapple farmers to express their response on a five point continuum viz., strongly agree, agree, undecided, disagree and strongly disagree with a score of 5,4,3,2 and 1, respectively for positive statements and reverse scoring for negative statements.

The maximum obtainable score by any respondent may be 70 and minimum obtainable score may be 14 . Based on the total score obtained by the respondents and calculating mean and standard deviation values they may be classified into three categories having highly favourable (score $>\mu+$ s.d), favourable (score in between $\mu+$ s.d and $\mu$-s.d) and less favourable (score $<\mu$ -s.d) attitude towards adoption of sustainable agriculture practices of Pineapple. The study concluded that scale developed to measure the attitude of farmers towards adoption of sustainable Pineapple cultivation practices based on Likert's technique was reliable and valid. Thus, the present scale can be used to measure the attitude of farmers towards adoption of sustainable agriculture practices and similar study areas by following the techniques followed in the study.

\section{Acknowledgement}

The corresponding author acknowledges the contributions of Dr. K.K.Jha, Professor \& Head, Department of Agricultural Extension, SASRD, Medziphema Campus, Nagaland University for his guidance, help, and making research facilities available for this work.

\section{References}

Blumberg, B., Cooper, D.R. and Schindler, P.S. 2005. Business research methods, Berkshire: McGraw Hill Education.

Chovatia, J.V., Kalsariya, B. N. and Kanani, M. K. 2017. Scale development for measuring the attitude of cotton growers towards drip irrigation system. Gujarat Journal of Extension Education, 28(2): 214-217.

Edwards, A. L. 1957. Techniques of attitude scale construction. Appleton Century Crofts Inc. New York.

Food and Agriculture Organization. 2015. http://www.fao.org/sustainabledevelopment-goals/overview/fao-andthe-post-2015-developmentagenda/sustainable-agriculture/en/ accessed on 16.10.2019.

Ghosh, M.K. and Hasan, S.S. 2013. Farmers' attitude towards sustainable agricultural practices. Bangladesh Research Publications Journal, 8(4): 227-234.

Kerlinger, F. N. 1987. Foundations of behavioral research. $3^{\text {rd }}$ edition. Holt, Rinehart and Winston.

Likert, R. A. 1932. Technique for the measurement of attitude. Archives of Psychology, New York, pp. 140.

Lin, Wei; Yang, Hsiao-Chi; Hang, Chi-Ming and Pan, Wen-Harn. 2007. Nutrition knowledge, attitude, and behavior of Taiwanese elementary school children. Asia Pacific Journal of Clinical Nutrition, 16(S2): 534-546.

Pallant, J. 2011. A step by step guide to data analysis using the SPSS Program: Survival Manual $\left(4^{\text {th }}\right.$ Edition $)$ McGraw-Hill, Berkshire.

Pimentel, L.J. 2019. Some Biases in Likert Scaling Usage and its Correction. International Journal of Sciences: Basic and Applied Research, 45(1): 183- 191. 
Rahman, M.Z., Mikuni, H. and Rahman, M. M. 1999. Towards sustainable farming development: The attitude of farmers in a selected area of Shimane Prefecture, Japan. Journal of Sustainable Agriculture, $14(4)$ : 19-33.

Ray, G. L. and Mondal, S. 1999. Research methods in social sciences and extension education. Kalyani Publishers, New Delhi.

Sadati, S.A., Fami, H.S., Asadi, A. and Sadati, S.A. 2010. Farmer's attitude on sustainable agriculture and its determinants: A case study in Behbahan County of Iran. Research Journal of Applied Sciences, Engineering and Technology, 2(5): 422-427.

Singh, A.S. 2014. Conducting case study research in non- profit organisations. Qualitative Market Research: An
International Journal, 17: 77-84.

Spearman, Charles, C. 1910. Correlation calculated from faulty data. British Journal of Psychology, 3: 271- 295.

Spector, P. E. 1992. Summated rating scale construction: An Introduction Sage University Papers Series. Quantitative Applications in the Social Science, 7: 082.

Thurstone, L.L. 1946. Comment. American Journal of Sociology, 52: 39-50.

WCED. 1987. Our common future. Report of the world commission on environment and development. G. H. Brundtland, (Ed.). Oxford: Oxford University Press.

Zeller, R.A. and Carmines, E.G. 1980. Measurement in Social Sciences: The link between theory and data, Cambridge University Press, London. pp. 54

\section{How to cite this article:}

Sentibenla Pongener and Kaushal Kumar Jha. 2019. Scale for Measuring the Attitude of Farmers towards Sustainable Cultivation Practices of Pineapple. Int.J.Curr.Microbiol.App.Sci. 8(12): 1163-1170. doi: https://doi.org/10.20546/ijcmas.2019.812.145 